Ankara Üniversitesi Türk Inkılâp Tarihi Enstitüsü Atatürk Yolu Dergisi

S 33-34, Mayıs-Kasım 2004, s. 103-130

\title{
Türk Harf İnkılâbı
}

\section{Dr. Neriman TONGUL*}

\section{ÖZET}

Türkler, İslam dinini kabul ettikten sonra, Arap alfabesi Türkler arasında yayılmış ve Türkçe'ye uygulanmıştır. Arap alfabesinin Türkçe'ye uygulanması sırasında, yazım kuralları sürekli değişmiş, ancak Türkçe için kullanışlı bir yazı oluşturulamamıştır. Bu nedenle 19. yüzyılın ikinci yansında, basın ve yayın hayatının gelişmesine paralel olarak alfabe tartışmaları başlamıştır. Yazının kolaylaştırılması ya da alfabenin değiştirilmesi yönünde başlayan tartışmalar, Cumhuriyet dönemine kadar-zaman zaman yoğunlaşarak- devam etmiştir.

Cumhuriyet'in ilk yıllarında devam eden tartışmaların sonunda Atatürk, alfabe konusunu inkılapları arasına alarak, 1928 yılında harf inkılabım gerçekleştirmiştir.

Okuma-yazmayı kolaylaştırmak, Türk milletinin eğitim ve kültür düzeyini yükseltmek, milli kültürü oluşturmak ve çağdaş uygarlı̆̆a yönelmek amacıyla yapılan harf inkılabı, başarıyla gerçekleştirilmiş ve bu amaçlara ulaşılmıştır.

\section{ABSTRACT}

Following the acception of the Islam religion by the Turks, the Arabic alphabet started to be used. The adaption of the Arabic alphabet brought the Arabic rules. As well some of these rules were not suitable to express the Turkish language. Therefore in the second half of the $19^{\text {th }}$ century debates on the simplification of the Turkish alphabet and the writing rules begun. These debates continued untill the first years of the republic.

Atatürk solved the problem by alphabet revolution in 1928.

The main goal of the alphabet revolution is to improve the education of the Turkish people and to bring the national culture to the contemporary level by making the people literate. Today, this goal has been achieved succesfully.

• Bilkent Üniversitesi Cumhuriyet Tarihi Bölümü. 


\section{CUMHURIYET'TEN ÖNCEKI GELISSMELER}

Türkler, tarih boyunca anayurtlarında ve yaptıkları akınlarda çeşitli topluluklarla ilişki kurmuş, bunlardan birçoğunu egemenlikleri altına almış, Şamanlıktan Müslümanlığa kadar ardarda çeşitli dinleri kabul etmişlerdir. Bunun sonucu olarak da Türkçe'yi yazmak için, dillerinin kuruluşuna uygun olsun olmasın çeşitli etkiler altında birçok yazı sistemleri kullanmışlardır. Bunların ilki, Türklerin kendi buluşu olan Kök-Türk alfabesidir. 500 yıllarında oluşturulduğu sanılan bu alfabe ile yazılı ve tarih taşıyan ilk anıt, Orhun Irmağı çevresindeki Kültigin Anıtı'dır.'

Bu yazı, Kök-Türk Devleti yıkıldıktan sonra (745), Yenisey ve Talas ırmakları çevresinde -bozuk bir biçimde- X. yüzyıla kadar kullanılmıştır, Batı'da da Hazar Türkleri tarafından XI. yüzyıla kadar kullanıldığı görülmektedir. Şaman dinine mensup Kök-Türkler'den sonra Uygur Türkleri, yeni bir Türk devleti kurduklarında (747-840), Soğdak, Mani ve Brahmi alfabelerinden oluşan Uygur Türkçesi geliştirmişlerdir. Orta Asya'da, Türkler arasında Uygur yazısı XI. yüzyıla kadar kullanılmış, Karahanlı Türklerinin X. yüzyılda İslamiyeti kabul etmeleri sonucu Arap harfleri benimsenerek Türkler arasında XI. yüzyılda yerleşmeye başlamıştır. Türkçe'nin yazıya geçirilmesinde hiç de elverişli olmamakla birlikte, Arap alfabesi Türkler arasında yüzyıllarca kullanılmıştır. Müslüman Türkler arasında Arap alfabesi yanında varlığını birkaç yüzyıl daha koruyabilen yalnızca Uygur Alfabesi olmuştur. ${ }^{2}$

Osmanlı Devleti genişledikçe dilimizde Arapça ve Farsça'nın etkisi giderek artmıştır. İstanbul, hilafet merkezi olunca, Osmanlı Devleti daha çok İslam karakterini almış, bunun sonucunda Arapça'ya daha çok önem verilmiştir. Medreselerde Arapça'nın önemi artarken, Farsça da edebiyat dili olarak tutunmuştur. ${ }^{3}$

Osmanlı Devleti genişledikçe Arapça ve Farsça kelimeler dilimize daha çok girmiş, bunun sonucunda Arapça, Farsça ve Türkçe'den oluşan Osmanlıca ortaya çıkmıştır. Türkçe gitgide önemini kaybederek Anadolu'da yaşayan Türk halkının konuşma dili olarak kalmış, buna karşılık Osmanlıca, devletin resmi dili ve aydın zümresinin kullandığı bir dil haline gelmiştir. Osmanlıca ağdalı, zor bir dil olduğu için, ancak çok uzun yıllar medrese öğrenimi gören aydınlar okuyup yazabiliyor ve konuşabiliyordu. Kırsal kesimde yaşayan Türk halkının büyük bir kesimi ise Osmanlıca'yı anlamak bir yana, kendi dilini bile yazıp okuyamıyordu.

1 Dilaçar, A. "Türk Yazısının Geçirdiği Evreler", Belgelerle Türk Tarih Dergisi, Dün-Bugün-Yarın, İstanbul - 1985, s. 11.

Tezcan, Semih "Türklerde Yazı Kültürünün Başlangıcı ve Gelişimi”, Harf Devrimi'nin 50. Yılı Sempozyumu, Ankara - 1981, s. 42-43.

${ }^{3}$ Karal, Enver Z. "Osmanlı Tarihinde Türk Dili Sorunu”, Bilim, Kültür ve Öğretim Dili Olarak Türkçe. Ankara - 1978, s. 48-96. 
Osmanlı Devleti'nde 1727 yılında matbaanın kurulması, Türkçe'nin önem kazanmasında etkili olmuştur. XVIII. yüzyılın ilk yarısında, orduya teknik eleman yetiştirmek amacıyla sivil okullar açılmış ve bu okullarda dersler Türkçe olarak verilmiştir. III. Selim ve II. Mahmut dönemlerinde askeri okullarda, çeşitli Avrupa dilleri arasında Türkçe'ye de yer verilmiştir.

Arap harflerinin değiştirilmesiyle ilgili ilk ciddi tartışmalar ve girişimler, 1860 yılından sonra başlamıştır. Çünkü Tanzimat döneminde yetişen ilk Türk aydın kuşağı, bilgilerini birikimlerini, fikirlerini halka yaymak amacıyla basın-yayın konusuna büyük önem vermiş ve ilk sivil gazetecilik girişimleri de bu dönemde başlamıştır. Basın-yayın hayatının doğmasıyla birlikte, ülkedeki okuma-yazma, dil, eğitim ve kültür sorunları gündeme gelmiş, dolayısıyla bu konulardaki en önemli araç olan alfabe ve dil aydınlar arasında tartışılmıştır. ${ }^{4}$

Arap alfabesinin iyileştirilmesi konusunda ilk ciddi girişim, Münif Paşa tarafından başlatılmıştır. Münif Paşa, üyesi olduğu Cemiyet-i İlmiye-i Osmaniye'de 1862 'de verdiği konferansta; hareke kullanılmadığı için bir kelimenin çeşitli biçimlerde okunabildiğini, anlamları bilinmeyen bazı kelime ve özel isimlerin okunmasının mümkün olmadığını, dilimizdeki Arapça-Farsça kelimelerin terkiplerinin çokluğunun, okuma-yazmayı büsbütün zorlaştırdığını, büyük harf olmadığı için özel isimlerin diğerlerinden ayırdedilmediğini, Avrupalıların ise yazılarında böyle zorluklar olmadığı için, 6-7 yaşından başlayarak her insanın okuyup yazabildiğini, bizde ise yazımızı öğrenmenin zorluğu yüzünden halkın fikren terbiyesinin mümkün olmadığını belirtmiştir. Ayrıca, Arap harflerinin kitap basımı için de uygun olmadığını, diğer milletlerin 30-40 harfle istedikleri kitabı basabildiklerini, bizde düzyazı ile kitap basabilmek için bile, yüzlerce işarete ihtiyaç bulunduğunu savunmuş, ${ }^{5}$ aynı konferansta, Latin harflerinin kolayca okunup yazılmasındaki yararları belirtmekle birlikte, bu konuya fazla değinmeyip, yazı sistemindeki zorlukları gidermek için şu önerilerde bulunmuştur: Alfabenin kolay okunabilmesi için harflere işaretier konulmalı, yeni sesli harfler bulunmalı, harfler ayrık yazılmalı. Bu şekilde birkaç basit kitap yazılır ve bunların faydaları görülürse, yaygınlaştırılabilir.

Konferanstan 14 ay sonra Azerbaycanlı şair Ahunzade Feth Ali, Cemiyet-i İlmiye-i Osmaniye'ye bir tasarı sunmuştur. Bu tasarıda; Arap harflerinin zorluğu, Arap harflerinin kullanılması için dini bir zorunluluk olmadığı ve yeni bir yazı sisteminin alınabileceği belirtilmiş, ancak Cemiyet bir rapor hazırlayarak, yüzyıllardır kullanılan bir yazının değiştirilmesinin zor bir iş olduğu sonucuna varmıştır. Bu konu üzerinde çalışan Encümen-i Daniş, 1763-1864 yılında Namık Kemal ile İran elçisi Melkum Han, bu

4 Tansel, F. Abdullah "Arap Harflerinin Islahı ve Değiştirilmesi Hakkında İlk Teşebbüsler (1862-1864)” Belgelerle Türk Tarih Dergisi, Dün-Bugün Yarın, İstanbul 1985. s. 16.

5 Mecmua-i Fünûn, 1868, s. 14, 74. 
konuyu Hürriyet gazetesinde tartıșmıșlardır. ${ }^{6}$ Melkum Han, ülkede eğitimin çok geri bir düzeyde olduğundan sözederek, Arap harflerinin sakıncalarını belirtmiş ve düzeltilmesi gerektiğini savunmuştur. Namık Kemal ise verdiği cevapta; alfabedeki değişikliğin zor olacağını, birçok kötülüklerin alfabeden değil, bilgi eksikliğinden kaynaklandığını, İngiliz, Amerikalı gibi milletlerin alfabeleri zor olmasına rağmen eğitimlerinin yüksek olduğunu belirtmiştir. Bununla birlikte, harflerin biçimlerini bütünüyle bozmadan, iyileştirmeye karşı olmadığını, ama devletin, böyle birşeye yanaşmak istemediğini kaydetmiştir.

Harflerin sadeleştirilmesi ve kolaylaştırılmasını savunanların arasına, Terakki gazetesi yazarı Hayrettin Bey, Ebüzziya Tevfik ve Ali Suavi de katılır. İbrahim Şinasi 1869 'da Avrupa'dan döndükten sonra bu konuyu ele almış, Arap harfleriyle nesih ve kûfi denilen yazı çeşitleri karması bir tür geliştirerek, matbaada kullanılan 500'den çok harf kasasını 112'ye indirmiş ve kendi matbaasında eserlerini bu şekilde bastırmıştır.

Arap alfabesinin iyileştirilmesi konusunda, 1862-1876 yılları arasında yapılan tartışmalar ve girişimler incelendiğinde, harflerin değiştirilmesini savunanlara göre, iyileştirme yanlılarının çoğunlukta olduğu görülmektedir.

Tanzimat dönemi aydınları Arap yazısının yetersizliğini ve düzeltilmesi gerektiği konusunu tartışılabilir bir duruma getirmekten öte bir şey yapamamışlardır. ${ }^{7}$ Yapılan birşey daha varsa o da; Tasvir-i Efkâr'da birtakım yeni işaretlerin kullanılmış olmasıdır. Böylece kalıplaşan yazım kuralları ilk yarayı almıştır. Alfabe ile ilgili birşeyler yapmak gerektiği ortaya çıkmış, kullanılan yazıya karşı bir kuşku doğmuş ve bundan sonraki alfabe çalışmalarına zemin hazırlamıştır.

II. Abdülhamit döneminde, 1878 yılında Sivas Mebusu Mehmet Ali Bey'in Eğitimle ilgili tasarıyı Meclis'e sunması tartışmaları yeniden başlatmıştır.

Namık Kemal, basın hayatına atıldı ̆̆ yıllardan başlayarak, gazetelerde, yazdığı makalelerde ve mektuplarında Arap harflerinin iyileştirilmesini savunurken, yazı değişikliğinin, özellikle Latin harfleri kullanılmasının şiddetle karşısında olmuştur. Bu dönemde tartışmalara katılanlar arasında Ebüzziya Tevfik, Hüseyin Cahit, Şemseddin Sami, Halit Ziya ve Mahmut Esat Efendi de yer alır.

Alfabe tartışmalarının sürdürülmesi sonucunda, bu dönemde yazım kuralları değişmeye başlamış, Türkçe sözcüklerde ünlülerin yazılması yoluna gidilmiş, her yazar kendine göre bir yazı sistemi geliştirmeye çalışmıştır. Bunların sonucunda, Edebiyat-1 Cedide dönemine (1896-1901)

6 Tansel, Abdullah, A.g.m., s. 17-18.

7 Canpolat, Mustafa, "Türkiye'de Yazı Devrimi Girişimleri”, Yazı Devrimi, Ankara -1979 , s. 24 
geçiş yıllarına rastlayan bir karışıklık ortaya çıkmıştır ki; artık işin özü genel ilkeler bir yana bırakılarak, tek tek sözcükler tartışılır hale gelmiştir.

1876-1908 yılları arasında, alfabe konusundaki tartışmaların ve görüşlerin geliştirilememesinin nedeni, siyasi koşulların elverişsizliği olmuştur. II. Abdülhamit' in istibdat yıllarında Arap harflerinde değişiklik ve yenilikler yapılması engellenmiştir.

II. Meşrutiyet döneminin başlamasıyla alfabe ve harf tartışmalarının yeniden şiddetlendiği görülmektedir. II. Meşrutiyet'in ilanından bir süre sonra, harf ve yazım kurallarını düzeltmek ve düzenlemek için, Maarif Bakanlığı tarafından komisyonlar oluşturulmuş, bunların yanısıra Islah-1 Huruf Cemiyeti gibi özel dernekler de kurulmuştur. Zamanla alfabe konusu, ülkedeki bütün aydınları ilgilendiren bir sorun haline gelmiştir. Bu alandaki görüşler; Arap harflerinin iyileştirilmesi ya da Arap harfleri bırakılarak Latin harflerinin kabul edilmesi olarak iki gruba ayrılmaktadır. ${ }^{8}$

Huruf-1 Munfasıla denilen harflerin ayrıklığı sistemini, Dr. Milaslı Hakkı Bey, Cihangirli M. Şinasi, İsmail Hakkı, Edebiyatçı Ali Nusret, Ahmet Hikmet ve Celal Esad yazdıkları kitap ve makalelerle desteklemişlerdir.

Enver Paşa, 1913 yılında Harbiye Bakanı olunca, özellikle Ordu'da uyguladığı yazı reformu, Paşa'nın tehditlerine rağmen yürütülememiştir. Ayrık harflerle yazılan bu yazıya "Ordu Elifbası", "Hatt-1 Cedit", "Enver Paşa Yazısı" gibi adlar da verilmiştir. Harbiye Bakanlığı tarafından, bazı resmi genelgeler bu yazı ile yazılıp orduya gönderilmiş ve askerliğe ait birtakım küçük kitaplar basılıp yayınlanmıştır. ${ }^{9}$ Ordu'da bir süre uygulanan bu yazı sisteminden, savaş yıllarında eski alışkanlığı bozduğu ve bu yüzden işleri geciktirdiği şikayetleri üzerine vazgeçilmiştir.

Huruf-1 Munfasıla girişimlerinin başarısız olmasının nedenleri; bu konudaki önerilerin mantıklı bir temele dayanmaması, farklı bir nitelik taşımaması ve öğrenimde kolaylığı sağlayamamasıdır.

Bu dönemde, harflerin ayrık yazılması ya da iyileştirilmesi çabalarının yanısıra Arap harflerinin bırakılarak, yerine Latin harflerinin kabul edilmesi görüşü de ortaya atılmıştır. Bu konuda; Hüseyin Cahit, Abdullah Cevdet, Celal Nuri İleri, Kılıçzade Hakkı gibi yazarlar, Latin harfleri ve buna dayanan yeni bir alfabe sistemi konusunda hayli cesur yayınlar yapmışlardır. O dönemde bunları yazmak, büyük bir medeni cesarettir. Bir yandan; Arap harflerinin sanki Allah tarafından gönderilmiş olduğu, onunla okumayazmanın bir din gereği bulunduğu gibi boş bir inanç, öte yandan; Latin harfleri kabul edilirse, eski bilim ve kültürümüzün mahvolacağı, eski ile olan

8 Ergün, Mustafa, Atatürk Devri Türk Eğitimi, Ankara - 1982, s. 88.

9 Enver Paşa'nın 1913-1914 yıllarındaki girişimi ile ilgili tartışmalar için bkz. Harf Devrimi'nin 50. Yılı Sempozyumu, Ankara - 1981, s. 55-60. 
bağlarımızın büsbütün kopacağı fikri yaygındır. ${ }^{10} \mathrm{Bu}$ sıralarda, Musullu Dr. Davut Bey, Mebusan Meclisi'ne bir tasarı sunmuş ve Latin harflerinin kabulünü önermiştir.

1910 yılında Tiranlı Arnavutlar, Latin harflerini kullanmak için sadrazamlığa başvurup izin isterler. Başvuru Şeyhülislamlığa gönderilerek fikri sorulur. Verilen cevapta; Kuran'ın Arap yazısından başka bir yazı ile yazılamayacağı ve okullarda okutulamayacağı bildirilir. Hüseyin Cahit, aynı yıl Tanin gazetesinde yazdığı "Arnavut Hurûfatı" başlıklı yazıda özetle; kullanmakta olduğumuz harflerin Türklük ve Müslümanlık'la ilgisi olmadığını, Türklerin kendi yazılarını bırakıp bunları sonradan kabul ettiğini, şimdiki Arap harflerinin Peygamber zamanında bile kullanılmadı̆̆ını, Arnavutların Latin yazısını kullanmalarına izin verilmesini, ona engel olmak bir yana, mümkünse bizimde bu yazıyı kullanmamızın yerinde bir hareket olacağını yazmıştır."

Yine devlet baskısı olmakla birlikte, 1910-1911 yıllarında Latin yazısı iyice savunulabilir duruma gelmiş, II. Meşrutiyet döneminin ilk beş yılında (1908-1913), bu konudaki tartışmalar ve fikirler daha da genişlemiştir. Bunda; "Maarifin terakkisi", "Halkın cehaletten kurtarılması" konularının bir devlet politikası olarak kabul edilmesinin rolü büyüktür.

Kılıçzade Hakkı ve arkadaşlarının çıkardığı Hürriyet-i Fikriye dergisinde, ${ }^{12}$ "Latin Harfleri" başlığı altında bütünüyle Latin harflerinin kabulünü destekleyip öneren bir seri makale yayınlanmıştır. Bu makalelerdeki bazı örnekler şöyledir: “....... madem ki, esaslı bir inkılâp yapılacaktır, gayrimükemmel ve uydurma harflerle Araplıktan çıkmış bir elifba yerine, her cihetçe mükemmel ve hususiyle el yazısında daima sadeliğini ve ittisalini muhafaza edebilen Latin harflerinin kabulü hem kestirme bir yol olur, hem de bunu takip edecek makalelerimde sirası geldikçe söyleyeceğim çeşitli faideleri temin eder ......."

“....... Şeyhülislâm yahut Fetva Emini hazretlerinden şu sualime bir cevap almayı pek arzu ederdim. Fransızlar, İslamiyet'in esaslarını pek makul bularak milletçe ihtida etmek istiyorlar. Acaba onları Müslüman edebilmek için o pek zarif dillerinin Arap harfleriyle yazılması şart-1 esasi mi ittihaz edilecek? "Evet" cevabını beklemediğim halde alırsam kemal-i cesaretle,

10 Ülkütaşır, M. Şahir, Atatürk ve Harf Devrimi, Ankara - 1981, s. 28.

" Tanin, 20-31 Ocak 1910, Şemsettin Bey ile kardeşi Abdül bey, Latin ve Yunan harflerinden seçtikleri harflerle bir Arnavut alfabesi meydana getirmişlerdir. Bu alfabede 36 harf bulunuyordu ve Arnavutça'yı en kolay şekilde ifade ediyordu. II. Abdülhamit döneminde bu harfler, Arnavut gençleri arasında yayılmıştı. Bu harflere karşı büyük çoğunluğu Müslüman olan Kuzey Arnavutlar muhalefet etmişlerdir. Ayrıca II. Meşrutiyet'in ilk yıllarında bazı azınlık aydınları tarafından çeşitli alfabeler yazılmıştır.

12 Yeni ve özgür fikirleri savunan ve tartışma konusu yapan bu dergi, zaman zaman Hükümetçe kapatılmış, önceleri Hürriyet-i Fikriye, sonra Serbest Fikir, daha sonra da Uhuvvet-i Fikriye adları ile yayımlanmıştır. 
"Siz bu zihniyetle dünyayı Müslüman edemezsiniz" mukabelesinde bulunurum. Hayır, "beis yok" cevabını alırsam, biz Türklerin de Latin harflerini kullanmamıza müsaade bahședer bir fetva veriniz, ricasını serd edeceğim. Hayır, Fransızlar ne kadar az Arap iseler, biz de o kadar az Arabiz.",13

Bu dönemde hız kazanan Türk milliyetçiliği düșüncesinin bir sonucu olarak dönemin aydınları arasında, kültürün en önemli ifade ve anlaşma aracı olan dilin ve yazının millileştirilmesi eğilimine açıkça rastlanmaktadır. Dönemin önemli düşünürlerinden olan Ziya Gökalp özellikle dil konusunda, Arapça'ya karşı Türkçe'yi savunanların başında yer almış ve “....... farzımuhal olarak birtakım müstebitçe kanunlarla İstanbul ahalisi bu acayip yazı diliyle konuşmaya başlamış olsaydı bile bu yazı dili gerçekten milli dil olmazdı." Diyerek bütün Türkiye'ye bu dilin zorla kabul ettirilemeyeceğini savunmuştur. ${ }^{14}$

Arap harflerinin iyileştirilmesi ve Latin harflerinin kabulü gibi iki grupta yoğunlaşan görüşlerden birincisi, sonunda pek bir başarı sağlayamamıştır. Çünkü bu konudaki fikir ve öneriler, alfabe ve eğitim sorunun büyüklüğü yanında kısır ve zayıf kalmıştır. Harflerin iyileştirilmesi çabalarının sonuç vermediğini ve vermeyeceğini, aydınların çoğu anlamıştır. Latin harflerinin kabulü yönündeki görüş ise aydınlar arasında daha çok benimsenmiş, gazete ve dergilerde yıllarca savunulmuş, Cumhuriyet döneminde gelişecek olan alfabe konusuna önemli ölçüde zemin hazırlanmıştır.

Milli Mücadele döneminde, 7-8 Ağustos 1919 gecesi Mustafa Kemal, Mazhar Müfit (Kansu)'i hatıra defteri ile birlikte yanına çağırarak ileride, Kurtuluş Savaşı kazanıldıktan sonra ülkede yapılacak olan yenilikleri yazdırırken, Latin harflerinin kabul edileceğine dair notu da yazdırmıştır. ${ }^{15}$

Alfabe konusu, Azerbaycan Hükümeti'nin Latin kökenli bir yazıyı 22 Temmuz 1922 tarihinde kabul etmesi üzerine, ülkede canlanıp yeniden ön plana geçmiştir. Azerbaycan Hükümeti'nin bu konudaki kararı ile ilgili yazı, 31 Temmuz 1922'de Ankara'ya ulaşmıştır. Bu yazının gelmesinden bir ay kadar önce (Haziran 1922) Gazi Mustafa Kemal Paşa Halide Edip'e, batılılaşmaktan ve Latin harflerini kabul etme olanaklarından söz etmiştir. ${ }^{16}$

12 Eylül 1922'de, aralarında Hüseyin Cahit ve Yakup Kadri'nin de bulunduğu İstanbul gazetecileri temsilcileri, İzmir'e giderek Gazi ile

13 Hürriyet-i Fikriye, Mart-Nisan 1914.

14 Albayrak, Mustafa, "Yeni Türk Alfabesinin Kabulü Öncesinde Türk Kamuoyunda Bazı Tartışmalar ve Millet Mekteplerinin Açılması (1862-1928), Atatürk Yolu, Ankara, Kasım - 1989, s. 476.

15 Kansu, Mazhar Müfit, Erzurum'dan Ölümüne Kadar Atatürk'le Beraber, Cilt I, Ankara - 1988, s. 131.

16 Ülkütaşır, M. Şakir, A.g.e., s. 42. 
görüşmüşler ve Hüseyin Cahit'in "Niçin Latin yazısını almıyoruz?" sorusuna Gazi, "Zamanı daha gelmemiştir." cevabını vermiş, bu konuda düşünerek ve acele etmeden adım adım ilerleme, "Harf İnkılâbının zamanını bekleme" yolunu tutmuş̧tur. 1922 Ekiminde Bursa öğretmenleri ile yaptığı bir görüşmede ise Türkçe'yi Arapça kalıplarından kurtarmak gerektiği fikrini savunmuştur.

Milli Mücadele dönemi, I. Dünya Savaşı'nın getirdiği olağanüstü koşullar sonucu, ülkede topyekün bir kurtuluş savaşının verildiği dönem olduğu için savaş dışındaki konular arka planda kalmış, dolayısıyla alfabe konusu, bu dönemde bir canlılık gösterememiştir.

\section{CUMHURIYETİN ILK YILLARINDA ALFABE TARTIŞMALARI}

\section{A - Atatürk'ün Alfabe, Eğitim ve Kültü̈r Konusundaki Görüşleri}

Son derece zor koşullar içinde kazanılan zafer sonunda kurulan yeni devletin, varlığını sürdürebilmesi ve sonsuza dek yaşaması, ancak çağın gereklerine ayak uydurabilmekle mümkündü. Atatürk'e göre, kurtuluşun tek yolu; bilimi, teknolojisi, kültürü ile yani "hayata bakış şekliyle" Batı uygarlığını herşeyi ile almaktı. Çünkü Atatürk, çağdaş uygarlığa yönelirken onun budanarak alınmasına kesinlikle karşı çıkmaktadır ve kesin sonuca ulaşabilmek için bütünüyle çağdaşlaşmak fikrindedir. Gerçekten $\mathrm{O}$, daha Milli Mücadele'nin en karanlık günlerinden başlayarak, sürekli "asrileşmek" ve "medenileşmek" zorunluluğundan bahsettiği gibi, zaferden iki ay sonra da, dünyadan kayıtsız yaşanamayacağını, modern ve çağdaş yaşamın bilim ve tekniği almayı gerektirdiğini belirtmiş, Lozan'dan kısa bir süre sonra, elde edilen başarının Türkiye'ye uygarlık yolunu açtı̆̆ını, gerekli olanın bu yol üzerinde durmadan ilerlemek olduğunu ifade etmiştir. ${ }^{17}$

Atatürk, "asrilik" ve "medenilik" kavramlarının anlam ve önemini, Türkiye Cumhuriyeti'ni dayandırdığı temellerden biri olan inkılâpçlık ilkesi ile işaret etmiştir. Bu ilkeyi uygulamak için giriştiği eylemler, Türk toplumunu bir kültür çeşidinden modern kültür kimliğine ulaştırma çabalarıdır. Kısaca; Atatürk inkılâplarının amacı, Türk insanını ve toplumunu bir an önce bugünkü uygarlığın bir ortağı haline getirmektir. Böylelikle Türkiye Cumhuriyeti'nin bağımsızlığı, Türk halkının huzur ve güven içinde yaşaması sonsuza dek sağlanabilecektir.

Atatürk, çağdaşlaşma yönünde değişimlerin ortaya çıkması, yani yeni kültür ögelerinin alınması ve toplumca kabul görmesi için, zamanındaki yetersiz, geleneksel kültür ögelerinin büyük bir çoğunluğunun terkedilmesi üzerinde ısrarla durmuştur. Örneğin; yönetim, ikili eğitim, Osmanlı yazısı,

17 Küçük Türk İslâm Ansiklopedisi, 3. fasikül, İstanbul - 1980, s. 219. 
geleneksel kıyafetler, toplum hayatı, evlilik, dini kurallara dayalı her türlü siyasi, hukuki davranışlar, v.s. ${ }^{18}$

Cumhuriyet'in ilk yıllarından başlayarak Atatürk ve arkadaşlarının üzerinde en yoğun çalıştıkları konuların başında, eğitimin gelmesinin nedenlerinden biri, hızlı gelişme isteği idi. Okur-yazarlığın çabucak yayılabilmesi için kolay ve basit bir alfabeye ihtiyaç vardı. Okuma-yazmayı kolaylaştırmak ve yaymak, modern eğitim ve öğretimi gerçekleștirmek ancak harf değişikliği ile sağlanabilirdi. Atatürk, harf değişikliğini, Türk kültürünün millileşmesi ve gelişmesini amaçlayan girişimin büyük bir adımı, bir parçası olarak görüyordu. Cumhuriyet döneminin çağdaşlaşma, Batı uygarlığına ulaşma ülküsü, harfler sorununu zorunlu olarak gündeme getirmişti.

1918 yıllarına ait anılarında Atatürk şunları yazmaktadır:

"Benim elime büyük bir salahiyet ve kudret geçerse ben içtimai hayatımızda istenilen inkılâbı bir anda bir "coup" ile tahakkuk ettireceğimi zannederim.

Halkı yeni fikirlerle eğitmek ve öğrenim durumunu yükseltmek gerekir. Aydınlar halkı kendi seviyelerine çıkarmalıdırlar. Bunun anlamı, toplumun eğitimini yeni ve kolay yöntemlerle sağlamaktır."19

1 Mart 1922'de Atatürk, T.B.M.M.'nin üçüncü toplantı yılını açarken şunları söylemiştir:

“....... Binaenaleyh, bizim takip edeceğimiz maarif siyasetinin temeli, evvela mevcut cehli izale etmektir. Teferruata girmekten ictinaben bu fikrimi birkaç kelime ile tavzih etmek için diyebilirim ki, genel olarak umum köylüye okumak, yazmak ve vatanını, milletini, dinini, dünyasını tanıtacak kadar coğrafi, tarihi, dini ve ahlaki malûmat vermek ve dört işlemi öğretmek, maarif programımızın ilk hedefidir." ${ }^{20}$

Büyük zaferden sonra TBMM'de konuşurken de;

“....... Efendiler; Artık vatan imar istiyor, zenginlik ve refah istiyor, ilmi marifet, yüksek medeniyet. Hür fikir, hür zihniyet istiyor.” diyerek sözlerini şöyle sürdürmüştür:

“....... Bütün bu hakikatlerin milletçe hüsnü telakki ve hüsnü hazmedilebilmesi için herşeyden evvel maarif programımızın, maarif

18 Çaycı, Abdurrahman, "Atatürk ve Kültür Alanında Çağdaşlaşma”, Atatürk Kültür ve Eğitim Semineri, 29 Kasım 1982, Kayseri.

19 İnan, Afet, “50. Yllında Türk Harf Devrimi (1928)" Harf Devrimi'nin 50. Yılı Sempozyumu, s. 79.

${ }^{20}$ Albayrak, M., A.g.m., s. 478. 
sistemimizin temel taşı cehlin izalesidir. Bu izale edilmedikçe yerimizdeyiz. Yerinde duran bir şey ise geriye gidiyor demektir.,"21

Özetle, Atatürk, harf inkılâbını, Türk toplumunu çağdaşlaştırmak yolunda bir araç, önemli bir basamak olarak görmüş ve Türk kültürünü halk kitlelerine yaymak, geliştirmek ve Türk halkının eğitim seviyesini yükseltmek, halk arasında kültür birliğini sağlamak amacıyla yeni Türk alfabesinin gerekliliği üzerinde önemle durmuştur.

\section{B - 1923-1928 Yılları Arasındaki Fikri Hazırlıklar ve Tartışmalar}

Milli Mücadele kazanıldıktan sonra, Şubat 1923 'te toplanan İktisat Kongresi'nde işçi delegelerinden İzmirli Nazmi ile iki arkadaşı tarafından Latin harflerinin kabulü hakkında bir önerge verildi. Ancak bu önerge, Kongre Başkanı Kâzım Karabekir Paşa tarafından, "Konunun daha çok maarifi ilgilendirdiği" ve "Latin harfleri İslâm birliğini bozacak" gerekçesiyle toplantıda okunmayarak reddedildi. Paşa, bu konudaki görüşlerini, kısa bir süre sonra basına "Latin Harflerini Kabul Edemeyiz" başlığı altında demeç vererek açıklamıştır. O'na göre; Latin harflerini savunanlar yabancıların propagandalarından etkilenmekte ve ülkeye zararlı bir fikir sokmaya çalışmaktadırlar. Türk dilini ifade edecek hiçbir Latin harfi yoktur. Bu fikirler Türk toplumunu etkilerse bütün İslâm alemi üzerimize hücum eder ve birbirimizi yeriz."22

Paşa'nın demeci, alfabe tartışmalarını yeniden başlattı. Latin harflerini istemeyenler, Paşa'dan aldıkları cesaretle yeniden güçlü bir yayına başladılar. Bu yayınlara karşı, Latin harflerini savunanlardan Kılıçzade Hakkı, İçtihad dergisinde, "İzmir Kongresinde Latin Harfleri" başlıklı üç makale yazarak, Paşa' ya verdiği cevapta şu görüşleri ileri sürmektedir: ${ }^{23}$

"Ne gariptir ki, yüksek bir tahsil görmüş çok zeki bir Kâzım Karabekir Paşa, o kadar fecayi-i tarihiye ve içtimaiyeden sonra, sırf îlmi bir mesele olan Latin harflerinin kabulü arzusunu takbih ediyor ve buna sebep olarak, hülasaten alem-i İslâm ne der? diyor. Evet alem-i İslâm ne der, işte bu kâbus!!! Bu tafsilattan sonra kendilerine bir sual iradına müsaade buyurmalarını Karabekir Paşa hazretlerinden rica ederim. Biz yalnız Müslüman mıyız? Yoksa hem Türk, hem Müslüman mıyız? Eğer biz yalnız Müslüman isek bize Arap harfleri ve Arap dili lâzımdır ve ilim olarak Kuran yetişir. Bunun yanında hakimiyet ve milliyet kavgaları ve davaları yoktur ve olamaz. Eğer Türk isek, bir Türk harsına muhtacız. Bu hars ise, herşeyden evvel dilimizden başlayacaktır.

Herkesi korkutan ve softalara, avama karşı büyük bir silah teşkil eden meseleye geliyorum. Kuran Latin harfleriyle yazılır mı?"

\footnotetext{
21 Söylev ve Demeçler, Cilt II, s. 33.

22 Hakimiyet-i Milliye, 5 Mart 1923.

23 İçtihad, Haziran, Temmuz, Ağustos 1923.
} 
Kılıçzade Hakkı, bir Türk'ün Kuran'1 bir Arap gibi okumasının mümkün olmadığını söyledikten ve Kuran'dan bir ayeti Latin harfleriyle yazdıktan sonra, "Bunu Latin harfleriyle şu şekilde yazmakta ne sakınca var?" diye sorar ve yazısını şöyle bitirir: "Lakin şurasını kafaya yerleştirmek şecaatini edinebilmelidir. Arabî harflerinden gayri harflerle Kuran yazmak küfür değildir ve böyle yapan küfür ve itaba layık olamaz, işte meselenin ruhu buradadır."

O günler, yeni kurulan Türkiye için kritik bir geçiş dönemi idi. Saltanatın kaldırılmasının yankıları hala devam etmekteydi. Nitekim İzmir'den Hüseyin Cahit'in, neden Latin harflerinin alınmadı̆̆ı konusundaki soruya Gazi, “....... zamanı daha gelmemiştir.” diye cevap vermişti. ${ }^{24}$ Latin yazısı aleyhtarlığı ülkede hala çok güçlüydü. Ancak, iyi bir zamanlama ustası olan Gazi, bu konuda da uygun bir zamanı bekliyordu.

Hüseyin Cahit, ayın yıl yazdığı yazıda şu görüşleri ileri sürmektedir:

“....... Bütün Türk matbuatının bastıkları gazetelerin yekunu, Avrupa'nın bir vilayet merkezindeki tek bir gazetenin adedi tab'ına uzaktan bile yaklaşamaz ....... biz de okuyup yazma bilenler nüfus sayımıza nispetle pek azdır. ....... Şu halde bu memleketi cehalet içinde hüsnü idare edebileceğimize nasıl ihtimal verebiliriz? Böyle bir hulyaya kapılacak olursak daha ilmin, fennin, sanatın lüzumunu bile anlamamış olduğumuzu ispat etmekten başka birşey yapmamış oluruz. ..... Biz memlekette ümmîliği azaltmıyoruz. Çünkü harflerimiz buna manidir. Çocuklarımız mekteplerde üç sene, dört sene çalıştıktan sonra da doğru okuyamazlar. Çocuklarımız değil hiçbirimiz her kelimeyi doğru telaffuz ettiğimizi iddia edemeyiz.

Böyle lisan, böyle tahsil olur mu? Bir köylü çocuğu senelerce mektebe gidip te, hiçbir şey öğrenemezse niçin vakit kaybetsin. Gazeteler okunamıyor, kitaplar okunamıyor, basılamıyor. Bizi şimdiki harflere rapteden şey nedir? Bu harfleri kullanmak için hiçbir mecburiyet-i diniye yoktur. Milli harflerimiz de değildir. Bu halde Latin harflerini kabul ederek, biran içinde herkese okuyup yazma öğretmek suretiyle elde edebileceğimiz namütenahi faydaları neden istihfaf ediyoruz?"25

TBMM'nin açıldığı günlerden başlayarak devam eden Türkçe dil konusu üzerindeki görüşler; 1923 yılında Tunalı Hilmi Bey tarafından verilen "Türkçe Kanun Teklifi” konusundaki öneriler, tutum ve davranışlar, Türk yazısı, Türk harfleri ve toplumun okuma-yazma sorunu olarak, ilk kez 1924 yılında Meclis'te açıkça tartışılmıştır. ${ }^{26}$

24 Atay, Falih R., Çankaya, İstanbul - 1984, s. 563

25 Resimli Gazete, 22 Eylül 1923, s. 3.

${ }^{26}$ Ankara Doğu Araştırma Merkezi, Eğitim ve Kültür Araştırma Grubu, Türk Yazı İnkılâbının Fikri Hazırlıkları”, BTTD, İstanbul - 1985, s. 37. 
25 Mart 1924'te TBMM'de söz alan İzmir Milletvekili Şükrü (Saraçoğlu) Bey, okuma-yazma konusuna değinerek, Arap harflerinin Türk dilini yazmaya uygun olmadığını, halkın okuma-yazma oranının düşüklüğünün sebebinin Arap harfleri olduğunu, İslâm dininin okumayı teşvik eden bir din olduğu halde, harfler yüzünden halkın okuyamadığını ve bunun büyük bir dert olduğunu belirtip, Maarif Vekaleti'nin bu konuda ne düşündüğünü ve ne yapabileceğini sormuştur. Bu sözler Meclis'te büyük bir gürültüye neden olmuş ve tutucuların saldırısına uğramıştır. Şükrü Bey’in sözleri basında ve kamuoyunda da tartışılmıştır.

3 Mart 1924'te, Tevhid'i Tedrisat Kanunu'nun kabul edilmesi ile bütün öğretim kurumları birleştirilip Milli Eğitim Bakanlığı'na bağlanmıştır. Aynı tarihte, Teşkilât-1 Esasiye'ye eklenen bir madde ile kız çocuklarının devlet okullarında ücretsiz eğitim görmeleri zorunlu hale getirilmiştir.

Aynı yıl, İkdam gazetesinde Mehmet Ali Tevfik, Resimli Gazete'de İbrahim Alâaddin (Gövsa), Gönül Hanım isimli kitabında yazar Müftüoğlu Hikmet, Latin harflerine karşı çıkan yazılar yayınlamışlardır. Yine aynı yıl, Berlin'de bulunan Türk öğrenciler, Latin harflerinin kabulünü isteyen bir dernek kurarak, "Yeni Yazı" dergisini çıkarmışlardır. Latin harflerinin lehinde ve aleyhinde yayınlar birbirini izlerken 25 Şubat 1925'te TBMM'de bu kez Milli Eğitim Bakanı olarak bulunan Şükrü (Saraçoğlu) Bey, harfler sorunu konusunda fikrini soranlara şu cevabı vermiştir:" "Efendiler, bendeniz Maarif vekiliyim ve Maarif vekili olmak hasebiyle memleketimizde harfler hakkında birçok cereyanlar olduğu için bu cereyanlardan herhangi birisine kuvvet verecek bir şekilde bu millet kürsüsünde söz söylemeyi faydalı değil, zararlı görüyorum."

1925 yılında, Cenab Şahabeddin, Servet-i Fünun dergisinde Latin harflerini savunmuş, 1926 yılında, Türkçü liderlerden Ayaz İshaki Türk Yurdu dergisinde yazdığı “Arap ve Latin Harfleri” başlıklı yazısında şunları yazmıştır: ${ }^{28}$ "Birkaç ay sonra Bakû'de toplanacak olan kongrede Latin harfleri kabul edilir ve Rusya Türkleri arasında uygulanırsa, bizim Anadolu Türkleri'nin önüne de gayet önemli bir hars meselesi çıkacaktır. Bu, büyük Türk milletinin ikiye bölünmesi, istikbalde birbirini anlamama meselesidir.”

Mart 1926'da, Bakû'de toplanan I. Türkoloji Kongresi'nde yapılan görüşmeler ve tartışmalar sonunda, Latin alfabesine geçiş prensibi benimsenmiş ve sonuç olarak her Türk kolu için Latin kökenli ayrı ayrı alfabeler oluşturulmuş, Kongre'yi izleyen yıllarda da uygulanmıştır. ${ }^{29}$ Aynı yıl Türkiye'de harfler sorunu yeniden canlanmış, Akşam gazetesinin 28 Mart 1926 tarihli "Latin Harflerini Kabul Etmeli mi, Etmemeli mi?" başlıklı anketi ülkede geniş yankılar uyandırmıştır. Dönemin ünlü yazar ve bilim

27 Levent, Agâh Sırrı, "Latin Harfleri Meselesi”, BTTD, s. 27.

28 Türk Yurdu, No: 6, 1926, s. 427.

29 Eren, Hasan, “Yazıda Birlik”, Harf Devrimi'nin 50. Yılı Sempozyumu, s. 85-89. 
adamlarından Halit Ziya, Necip Asım, Veled Çelebi, Ali Canip, İbrahim Alaaddin, Prof. Zeki Velidi Togan, Avni Başman, Yusuf Semih, Ali Seydi, Prof. Köprülüzade Mehmet Fuat gibi kişiler Arap harflerini savunurken, Refet Avni, Abdullah Cevdet, Mustafa Hamit gibi aydınlar da Latin harflerini savunmuşlardır. Savunanların gerekçeleri şunlardır: almak.

1. Halka okuma-yazmayı daha kolay öğretecek bir yazı sistemini

2. Türkçe'nin zenginliğini ve canlılığını daha iyi ortaya koyup gelişmesini sağlamak.

3. Uygar milletlerle iletişim sağlamak.

Alfabe tartışmaları ile ilgili daha birçok yazılar yayınlanmıştır. Latin harflerinin lehinde yazılan yazılardan birisi de Kılıçzade Hakkı'nın Hür Fikir dergisinde çıkan "Arap Harflerini de Cebrail Getirmedi Ya!” başlıklı makalesidir. ${ }^{30}$

3 Haziran 1927'de, Bakû Kongresi'nde oluşturulan Merkezi Komite, Moskova'da yaptığı toplantıda, Latin alfabesinin nasıl kullanılacağına karar vermiş ve bu karar Paris'teki bir sergi ile bütün dünyaya duyurulmuştur. Böylece Müslüman Arnavutluk'tan sonra, Asya Türkleri de Latin alfabesini kabul etmişlerdir. Bu kararla, Latin harflerinin Müslüman Türkler arasında ayrılık yaratacağını savunanlar da önemli ölçüde tatmin edilmişlerdir. ${ }^{31}$

Arap harflerini bırakmak istemeyenlerin korkusu, yüzyılların ortaya çıkarmış olduğu eserlerin bir anda unutulacağı ve geçmişle olan manevi bağın kopacağı noktasında toplanmış bulunuyordu. Halbuki Türk İnkılâbı bir bütündü. Batı uygarlığına girmek amaç olduğuna göre, yaşama araçları gibi, yazma, okuma ve düşünme araçlarını da bu uygarlığa göre ayarlamak gerekiyordu. Latin harfleri uzun bir süre Fransız harfleri sanıldığı için birçok itirazlara yol açtı. Aslında yapılmak istenen Latin kökünden Türkçe'nin kendi yapısına uygun yeni bir alfabe oluşturmaktı.

1927 yılının sonları ve 1928 yılının ilk yarısı, Latin harflerinin Türkçe'ye uygulanması yolunda, çok hareketli bir dönem olmuştur. Hakimiyet-i Milliye'de Falih Rıfk1, Cumhuriyet'te Yunus Nadi, İkdam'da Celal Nuri, Tanin'de Hüseyin Cahit, Latin harflerini savunarak bu fikri yaymaya çalışmışlar, bu konu ile uğraşanlar, fikir ve önerilerini açıkça ortaya koymuşlardır. Ahmet Cevat'in Vakit gazetesinde, 1927 sonundan 1928 başına dek yazdığı yazılar ${ }^{32}$ ve İbrahim Necmi (Dilmen)'nin Milliyet

3. Hür Fikir, 17 Kasım 1926.

31 Albayrak, M., A.g.m., s. 482.

32 Bu yazılar daha sonra, "Muhtaç olduğumuz Lisan İnkılâbı Üzerinde Bir kalem Tecrübesi” adıyla kitap olarak yayınlanmıştır. 
gazetesinde Mayıs-Ağustos 1928'de yazdığ1 "Latin Harfleriyle Türk Alfabesi" başlıklı yazıları, harf inkılâbından önceki son denemelerdir.

\section{C-Harf İnkılâbı'nın 1928 Yılında Gerçekleşmesinin Nedenleri}

Yeni Türk harflerinin kabulünün 1928 yılında gerçekleşmesi rastlantı değildir. Bunun önemli nedenleri vardır. Yazı değişikliği, herşeyden önce yeni kurulan Türk devletinin gerektirdiği yeniliklerden biridir. Çünkü Cumhuriyet, köklü bir düzen ve siyasal yapı değişikliğidir. Osmanlı Devleti'nin çağdışı kurumlarını yıkmak, kültürel değerlerini, millileşme ve çağdaşlaşma doğrultusunda değiştirmek girişimleridir. Bu girişimlerin gerçekleşmesi, büyük ölçüde Türk toplumunun, Cumhuriyet'in getirdiği yeni değerleri benimsemesine, yaşantısını bu değerlere göre düzenlemesine bağlıdır. Yazı, çağdaş uygarlık değerlerini Türk insanının yaşantısına geçirmede bir araçtır. Başka bir deyişle, toplumun hem alt yapısını hem de üst yapısını belirleyen çok boyutlu bir araçtır. Bu anlamda, eski kültür değerlerini bırakıp yenilerini alabilmek için harf inkılâbı zorunlu olmuştur.

Ancak, bu yolda bilinçlenme kolay olmamış, alfabe sorunu geçirmesi gerekli aşamaları bir bir yaşamıştır. Her kültür değişikliği olayının ardında olduğu gibi, bu sorunun ardında da altmış yılı aşkın önemli bir geçmiş ve birikim vardır. Buna rağmen, Cumhuriyet'in ilk yıllarında harf inkılâbını gerçekleştirmek mümkün olamamıştır. Çünkü yazı, kültürün en belirgin ve etkin araçlarından biri olduğundan, yazının değişmesi, bir toplumun bütün kültür değerlerinin yok olması anlamına gelir ki; yaklaşık bin yıldır kullanılan ve kök salan Arap yazısının atılması, bu bakımdan hiç de kolay olmamıştır. Arap alfabesine dayalı olan yazı, eski toplumun ve eski kültürün bir simgesidir. Dolayısıyla eski siyasal iktidarın da ayrılmaz bir parçasıdır. Ayrıca Arap yazısı Kuran'ın yazısı niteliğini taşıdığı için Türk toplumunun gözünde kutsal bir anlamı da vardır.

Bunlara karşılık, Atatürk'ün çağdaşlaşmak amacıyla yaptığı girişimleri açıklayan "inkılâp" kavramının temelinde önemli bir bilimsel ilke bulunmaktadır. $\mathrm{Bu}$, bir toplumda kültürel yapının değişmesi için yeni kabul edilecek kültür değerlerinin, alıcı toplumun eski kültür değerleri ile uyuşması gerektiğidir. Atatürk, bu bilimsel gerçeği tüm eylemlerinde en başta dikkate almıştır. Bu nedenle, Batılı kültürle uyuşmayacak olan İslâm dinine dayalı kültür değerlerinin terkedilmesini istemiş ve bunların yerine alınacak yenilikler ile uyuşmayı sağlayacak yeni bir temel kültür ögesini "Laiklik" ilkesini ve kavramını getirmiştir.

Nitekim Atatürk, bu uyuşmazlığı şöyle açıklamıştır: "Türk toplumunun üzerindeki dini baskının olumsuz etkilerini kaldırmak suretiyle, Türkiye'de radikal bir batılılaşma ve modernleşme sağlanabilir." ${ }^{33}$

33 Erdentuğ, Nermin, “Atatürk'te Kültür Dinamizmi Görüşü”, Cumhuriyet'in 50. Yıldönümü Anma Kitabı, Ankara - 1974, s. 73. 
O halde Türk toplumunu geleneksel kültür tipinden, modern kültür tipine doğru dönüştürme çabalarında herşeyden evvel, laiklik ilkesine dayanmanın zorunlu olduğu açıktır. Başka bir deyişle laiklik gerçekleşmeden köklü yeniliklerin yapılması mümkün değildir.

M. Canbolat'a göre; “....... 1862 dolaylarında başlayan ve oldukça uzun bir serüven geçirdikten sonra, Cumhuriyet dönemine değin gelen Latin harfleri konusu, Büyük Atatürk'ün ișe el koymasıyla, çok kısa bir süre içerisinde çözüme ulaşmıştır. Daha önce olabilir miydi? sorusu akla gelebilir. Yanıtım, olamazdı biçiminde olacaktır. Yazı değişimi gerçekte Atatürk devriminin bir parçasıdır. Laiklik ilkesi benimsenmeden bir yazı değişikliği yapılamazdı. Ekin siyasamızda köklü değişiklikler yapılmadan bir yazı değişikliği yapılamazdı. İmparatorluk düzeni içerisinde bir yazı değişikliği yapılamazdı. Ulusçuluk akımı gelişmeden bir yazı değişikliği yapılamazdı. Kısacası Cumhuriyet kurulup, Atatürk ilkeleri birer birer kurumlaşmaya başlamadan bir yazı değişikliği yapılamazdı." ${ }^{34}$

Gerçekten de harf İnkılâbı'na kadar geçen süre içinde "laiklik" ilkesine bağlı kalınarak, ülkede yapılması tasarlanan yeniliklerin büyük bir bölümü tamamlanmıștır. 1924'te Hilafet ile Şer'îye ve Evkaf Vekaleti kaldırılmış, bütün okullar Milli Eğitim Bakanlığı'na bağlanmış, 1925'te tekke ve zaviyeler kapatılmış, kılık-kıyafet değiştirilmiş, 1926'da Medeni Kanun kabul edilmiştir. 1926 'da eğitim işleri yeniden düzenlenmiş, ilk ve orta öğretimin esasları saptanmış, çağdışı bütün dersler kaldırılmış, çağdaş eğitim ve öğretim yapacak okullar açılmıştır.

Bütün bu atılımlarla Harf İnkılâbı'na geçişi kolaylaştıracak olanaklar yaratılmıştır. 1925 yılından 1929 yılına kadar süren Takrir-i Sükûn dönemi de, gerek diğer inkılâpların, gerekse Harf İnkılâbı'nın gerçekleşmesi için uygun ortamın hazırlanmasında önemli bir etken olmuştur.

İsmet İnönü, "Hatıralar"'nda Harf İnkılâbı ile ilgili Atatürk'le arasında geçen konuşmaları şöyle aktarmaktadır: ${ }^{35}$

"Harf İnkılâbı ilân edilmeden iki sene evvel Atatürk'e söyledim:

- Bu kolay değildir. Sen Harp zamanı karargâhta çalıştın mı?

- Hayır, dedi.

- Ben bilirim dedim. Bunu tecrübe ettim. Bütün devlet muamelâtı herşey bozulacak. Herkes iki yazı kullanacak. Kabul edildi diye kendisini mecbur hissedecek, yeni harfleri kullanacak, bir de asıl işidir, kıymetli işidir diye eski harfleri kullanacak. Başa çıkamayız iyi düşün.

34 Canbolat, Mustafa, “Türkiye'de Yazı Devrimi Girişimleri”, Yazı Devrimi, Ankara -1979 , s. 22-23.

35 İnönü, İsmet, Hatıralar, Cilt II, Ankara 1987, s. 221-222. 
Atatürk'e bunları söyledim ve benim ikazım cesaretini kırdı. Harf İnkılâbı'nı iki sene sürükledi. Resmi beyanlarında, grupta, partide yaptığı konuşmalarda, yeni harfleri düşünüyoruz diyordu."

İnönü aynı eserinde Harf İnkılâbı ile ilgili şunları da yazmıştır:

“....... Harf İnkılâbı bir okuma-yazma kolaylığına bağlanamaz. Okumayazma kolaylığı, Enver Paşa'yı tahrik eden sebeptir. Ama Harf İnkılâbı'nın bizde tesiri ve büyük faydası, kültür değişmesini kolaylaştırmasıdır. İster istemez Arap kültüründen koptuk. Arap kültürünün ve Arap dilinin tesiri hakkında yeni nesiller bizim kadar fikir edinemezler. Bir misal olarak söylemek isterim. Benim çocukluğumda kültür sahibi adamlar Türk dilinin kifayetsizliğinden, eksikliğinden meyis olarak bahsederlerdi ve bunun için cemiyet içinde, hem Türk diye bir millet olarak, Arap'tan ayrılığı kaldırmalıydık, hem de sağlam bir dile kavuşmak maksadıyla Arapça'yı kabul etmeliydik derlerdi. Yani vaktiyle devleti kurarken ve Türk dilini yaparken Arap dilini kabul etmek doğru olacaktı, görüşünü hararetle savunurlardı."

H. Eren'e göre; "Atatürk belki Rusya'daki çalıșmalarını düşünmeden de, eskiden beri bu konularda fikir beyan etmiștir. Fakat bu fikirlerin birdenbire 1928 'de gerçekleştirilmesi, hiç olmazsa Bakû'deki çalışmalarla ilgilidir sanırım. Bakû Kongresi, bu reformun bir an önce ele alınmasını çabuklaştırmıştır." 36

Bernard Lewis ise, Sovyetlerin ülkelerindeki Türkler için Latin yazısını kabul etme nedenlerinin, Türkiye ile teması kesmek olduğunu, ama bunun Türkiye'de ters bir etki yaratıp Latin harflerinin kabulünü desteklediğini, Türkiye'deki Azerbaycanlı sürgünlerin Latin harfleri propagandası yaptığını, bunun da, Gazi'nin politikasına uyduğunu, ancak Gazi'nin asıl amacının, yeni yazı ile birlikte eski düzen ve fikirlerin geçmişe gömülüp, yalnız Latin harfli Türkçe'de ifade edilen fikirlere açık yeni bir kuşak yetiştirmek olduğunu ifade etmektedir. ${ }^{37}$

H. Bayur, Harf İnkılâbı'nın 1928 yılında yapılması ile ilgili düşüncelerini şöyle açıklamaktadır:

"Atatürk bir işe girişirken gerek iç, gerek diş durumu inceler ve ona göre davranırdı... Atatürk esaslı ve uzun zaman alacak bir devrime, bir harekete giriştiği vakit, etrafı gayet iyi kollar, yani o yapacağı hareketi durdurmak mecburiyetini yaratacak bir hadise ihtimali var mı? bunu kollar ve gayet de iyi takdir eder... Şimdi iç durumu ele alalım. Atatürk'ü en çok sıkan ittihatçı tarizleriydi. İttihatçı tarizleri suikasttan (1926) sonra

.36 Eren, Prof. Dr. Hasan, "Yazıda Birlik", Harf Devrimi’nin 50. Yılı Sempozyumu, s. 88 .

37 Lewis, Bernard, Modern Türkiye'nin Doğuşu, Ankara - 1984, s. 427-428. 
tamamiyle ezilmiştir. Binaenaleyh orada bir sinmişlik vardır, oradan artık korkulmaz.

İkincisi dışarıda, Yunanistan'la dostluk başlamıştır. Yunanistan'la dostluk demek Avrupa ile olan gücenikliğimizin, kırgınlığımızın izalesi demektir. Çünkü o vakte kadar Batı Avrupa bize fena gözle bakıyordu ve bizi almıyordu arasına. Ama Yunan vasıtasıyla o tarafa yaklaşmış olduk." Avrupa'daki askeri ve siyasi durumların da Atatürk'e zaman kazandırdığını ifade eden Bayur, sözlerini şöyle tamamlamıştır:

“....... Mussolini de kâfi derecede kök salmamıştı. Memleketinde muhalifi çoktur. Sağa-sola çatacak durumda değildir. Bu esaslar dahilinde bunlara bakarak Atatürk, birkaç yıl uğraştıracak ve kendisine zaman sağlayacak bir durum görmüştür. Bu işe girişmiştir." ${ }^{38}$

\section{HARF INNILÂBININ GERÇEKLEŞMESİ}

1928 yılında, yeni Türk harflerinin kabul edilmesine kadar geçen süre içinde konuyla ilgili olayların ilki, Adalet Bakanı Mahmut Esat (Bozkurt)'ın, Türk Ocakları Merkez ve Hars Heyetlerine verdiği bir şölende, Latin harfleri lehindeki konuşmasıdır. Aynı yıl 8 Mart'ta Başbakan İsmet İnönü, Türk Ocağı Hars Heyetinde Latin harfleri üzerinde bir danışma toplantısı yapmıştır.

20 Mayıs 1928 günü, CHP Genel Sekreteri Saffet (Arıkan) Bey ile arkadaşlarının hazırladıkları "Latin Rakamları Tasarısı" Meclis'te kabul edilmiş. Aynı gün, konu Meclis'te görüşülürken, Hasan Fehmi Bey yeni harflerin ne zaman kabul edileceğini sorduğunda, söz alan Maliye Bakanı Şükrü (Saraçoğlu) Bey, şunları söylemiştir:

“....... Harfler meselesine gelince; kezalik TBMM'nin şimdiye kadar ittihaz ettiği büyük kararlarda kendine meslek ittihat ettiği büyük bir şiarı vardır ki, herhangi bir mesele, muazzel bir mesele bilhassa ilmi ve fenni bir mesele halledileceği zaman, bütün kuvvet ve kudretin kendi elinde olduğunu bilmekle beraber TBMM, daima ilim ve fen mebahisinde bilhassa mütehassısların, alimlerin ve mütefenninlerin birarada toplanarak bir noktada ittihat ettikleri gün, onu birgün dahi tehir etmeksizin heyet-i celilenize takdim edeceğiz..." ${ }^{39}$

Şükrü Bey'in konuşmasından sonra Milli Eğitim Bakanı Mustafa Necati Bey söz almış, konunun üzerinde ciddiyetle çalışıldığını ve kısa bir süre sonra Meclis'e takdim edileceğini belirterek, TBMM üyelerini bu konuda bilgilendirmiştir. Bu konuşmalardan sonra, basında Latin harfleri yeniden tartışılmaya başlanmış ve yazıların çoğu Latin harflerini savunmasına

\footnotetext{
38 “Tartışmalar ve Açıklamalar”, Harf Devriminin 50. Yılı Sempozyumu, s. 91.

39 T.B.M.M. Zabıt Ceridesi, Dönem II, Cilt 6, s. 334.
} 
rağmen halâ Arap harflerinin olduğu gibi kalmasını ya da iyileştirilmesini savunan yazılar da yer almıştır.

20 Mayıs 1928 günü Bakanlar Kurulu, alfabe konusunu incelemek, bu konudaki çeşitli görüşleri saptamak ve fikirlerini belirtmek üzere "Dil Encümeni" adlı bir komisyon kurulmasına karar vermiştir. Bu komisyon; üçü milletvekili (Falih Rıfkı, Ruşen Eşref, Yakup Kadri), üçü eğitim yüksek memuru (Mehmet Emin Erişingil, İhsan Sungu, Avni Başman), üçü de uzman (Ragıp Hulusi Özden, İbrahim Grandi, Ahmet Cevat Emre) olmak üzere 9 üyeden oluşuyordu. Daha sonra Fazıl Ahmet, İbrahim Necmi, Ahmet Rasim, Celal Sahir ve İsmail Hikmet'in katılmasıyla komisyonun üye sayısı 14'e çıkmıştır. Bu komisyon Fransız, İngiliz, Alman, Macar gibi birçok milletlerin alfabelerini inceledikten sonra, 26 Haziran'da Atatürk'ün başkanlığında ilk toplantısını yapmışır.

Komisyon, iki rapor hazırlamıştır: Birisi "Gramer Hakkında Rapor", diğeri ise "Elifba Raporu"dur. "Elifba Raporu", Ağustos 1928'de, Cumhurbaşkanı Mustafa Kemal Paşa'ya sunulmuştur. Bu rapor, Yeni Türk alfabesi konusunda ilk resmi ve bilimsel rapor özelliğini taşımaktadır. ${ }^{40}$

Dil Encümeni, bu çalışmaları yaparken, kendi aralarında seçtikleri üç kişiden oluşan "Latin Alfabesi Komisyonu"nu kurmuştu. Bu komisyon bir yandan, Dil Encümeni'nin çalışmalarına yardımcı olacak, diğer yandan, Latin yazısı, özellikle Fransız alfabesi ile Türk yazı değişiklikleri konusundaki inceleme ve araştırmaları yapacak ve görüşleri belirleyecekti. Komisyonun hazırlamıș olduğu rapor, 12 Ağustos 1928 günü Cumhurbaşkanlığı'na verilmiştir.

Başbakan İsmet Paşa da, Alfabe Komisyonu'na girmiş, 17 ve 19 Temmuz tarihli toplantılarda, yeni alfabeye "Türk Alfabesi" adını o vermiştir.

$\mathrm{Bu}$ arada, Milliyet gazetesi, yeni alfabe kampanyasına başlayarak Dil Encümeni üyelerinin hazırladı̆̆ı alfabeyi 26 Haziran'dan itibaren kullanmıştır. ${ }^{41}$

Temmuz ayının sonlarına doğru, Falih Rıfkı, Mehmet Emin ve Ahmet Cevat, Dolmabahçe Sarayı'na gelerek, Mustafa Kemal Paşa'ya alfabe raporunu sundular. Paşa, yeni yazıyı uzun uzun inceledikten sonra, Falih Rifkı'ya sordu:

"Yeni yazıyı tatbik etmek için ne düşündünüz?

40 Ankara Doğu Araştırma Merkezi Eğitim Araştırma Grubu, "Dil Encümeni Çalışmaları", BTTD, s. 63.

${ }^{41}$ Şimşir, N. Bilal, "Amerikan Belgelerinde Türk Yazı Devrimi”, Belleten, C. XLIII, s. $110-111$. 
- Bir onbeş yıllık uzun, bir de beş yıllık kısa mühletli iki teklif var... Teklif sahiplerine göre, ilk devirler iki yazı birarada öğretilecektir. Gazeteler yarım sütundan başlayarak yavaş yavaş yeni yazılı kısmı artıracaklardır. Daireler ve yüksek mektepler için de tedrici bazı usuller düşünülmüştür.

Yüzüme baktı:

- Bu ya üç ayda olur, ya hiç olmaz, dedi.

Hayli radikal bir inkılâpçı iken, ben bile yüzüne bakakalmıştım.

- Çocuğum, dedi. Gazetelerde yarım sütun eski yazı kaldığı zaman dahi, herkes bu eski yazılı parçayı okuyacaktır. Arada bir harp, bir iç buhran, bir terslik oldu mu, bizim yazı da Enver'in yazısına döner. Hemen terkolunuverir., ${ }^{42}$

Nihayet konunun artık olgunlaştığını gören Mustafa Kemal Paşa, harekete geçerek 9 Ağustos 1928 günü akşamı, CHP'nin Sarayburnu Parkı'nda düzenlediği eğlencede, büyük inkılâpla ilgili ilk müjdeyi halka vermiş ve İnkılâbı şu sözlerle başlatmıştır:

"-Sevgili Kardeşlerim;

Huzurunuzda ne kadar bahtiyar olduğumu izah edemem. Duygularımı tek tek kelimelerle ifade edeceğim: Memnunum, mütehassısım, mesudum. Bu vaziyetin bana ilham ettiği hissiyatı huzurunuzda ufak notlar halinde tespit ettim. Bunları içinizden bir vatandaşa okutacağım."

Paşa, elindeki küçük notları orada bulunanlardan bir gence verdikten sonra tekrar sözlerine devam etti:

"Vatandaşlar, bu notlarım asıl, hakiki Türk kelimeleri, Türk harfleriyle yazılmıştır. Kardeşiniz bunu derhal okumaya teşebbüs etti; birdenbire okıyamadı. Biraz çalıştıktan sonra şüphesiz okuyabilir. İsterim ki bunu hepiniz beş-on gün içinde öğrenesiniz.

Arkadaşlar, bizim ahenkdar, zengin lisanımız, yeni Türk harfleriyle kendini gösterecektir. Asırlardan beri kafalarımızı demir çerçeve içinde bulundurarak, anlaşılmayan ve anlayamadığımız işaretlerden kendimizi kurtarmak, bunu anlamak mecburiyetindesiniz. Anladığınızın âsarına yakın zamanda bütün kâinat şahit olacaktır. Buna kat'iyetle eminim. Yeni Türk alfabesiyle yazdığım bu notları bir arkadaşa okutacağım, dinleyiniz."

Paşa, elindeki notları bu kez Falih Rıfkı'ya verip kalan bölümü ona okuttuktan sonra tekrar söz alarak şunları söyledi:

"Vatandaşlar, Arkadaşlar!

42 Atay, Falih R., Çankaya, İstanbul - 1984, s. 440. 
Çok söz, uzun söz birşey için söylenir, hakikati anlamayanları hakikate getirmek için... Ben bu devirleri geçirdim, şimdi sözden ziyade iş zamanıdır. Artık benim için, hepimiz için çok söz söylemeye ihtiyaç kalmadı kanaatindeyim. Bundan sonra bizim için faaliyet, hareket ve yürümek lâzımdır. Çok işler yapılmıştır, amma, bugün yapmaya mecbur olduğumuz son değil, lâkin çok lüzumlu bir iş daha vardır: Yeni Türk harflerini çabuk öğrenmelidir. Vatandaşa, kadına, erkeğe, hamala, sandalcıya öğretiniz. Bunu, vatanperverlik ve milletperverlik vazifesi biliniz. Bu vazifeyi yaparken düşününüz ki, bir milletin, bir heyet-i içtimaiyenin yüzde onu okuma-yazma bilir, yüzde doksanı bilmez nevidendir. Bundan insan olanlar utanmak lâzımdır. Bu millet utanmak için yaratılmış bir millet değildir. İftihar etmek için yaratılmış, tarihini iftiharla doldurmuş bir millettir. Fakat milletin yüzde sekseni okuma-yazma bilmiyorsa, bu hata bizde değildir. Türk'ün seciyesini anlamayarak, kafasını birtakım zincirlerle saranlardadır. Artık mazinin hatalarını kökünden temizlemek zamanındayız. Hataların tashih olunmasında bütün vatandaşların faaliyetini isterim. En nihayet bir sene, iki sene içinde bütün Türk heyet_i içtimaiyesi yeni harfleri öğreneceklerdir. Milletimiz, yazısı ile, kafası ile bütün alem-i medeniyetin yanında olduğunu gösterecektir.",

9 A ğustos 1928 gününden sonra, ülkenin her tarafında aydınlarla halk, yeni harfleri öğrenmek, öğretmek için yarışa girmiş, alfabeler basılmış, gazeteler dersler yayınlamış, 8-10 satırdan başlayarak uzun yazılara, bütün bir sayfaya kadar yeni Türk harfleri ile yayın yapmak, başlıklarını değiştirmek gazeteler için eğlenceli bir iş olmuştu. Bir taraftan da halka, yeni harflerin tablosunu veriyorlardı. 16 Ağustos günü CHP'de yapılan bir toplantıda, yeni harflerin yayılması için gerekli önlemlerin alınması ve her semtte bir dersane açılması kararlaştırılmıştı. Bu dersaneler için aynı yıl "Halk Dersanelerine Mahsus Türk Alfabesi” basıldı. Bu arada İstanbul Belediyesi, telefon rehberinin, gelecek yıl yeni harflerle basılması için emir vermişti. Ticaret Odası'nda 15 Ağustos'tan sonra imzalar yeni harflerle atılmaya başlandı. Yazışmalarda da bu harfler kullanılacaktı. İstanbul'da ve Ankara'da bazı devlet dairelerinde yeni kurslar açılmıştı. Adalet Bakanı, Kasım ayında verilecek hukuk diplomalarının yeni harflerle yazılmasını emretmişti. ${ }^{44}$

$\mathrm{Bu}$ arada eğitim, müfettişleri için kurslar açılmış ve yeni harfleri öğrendikten sonra, öğretmenlere öğretmekle sorumlu tutulmuşlardı. 21 Ağustos'ta, Darülfünun, yeni harfler üzerine konferanslar düzenlemeye başladı. Devlet basımevi, gerekli harfleri İstanbul'da döktürüp kitap basmaya hazırlanmış, Milli Eğitim Bakanlığı'na ilk yeni harfle dilekçe, 21 Ağustos'ta verilmişti. ${ }^{45}$

\footnotetext{
${ }^{43}$ Atatürk, M.K., "Türk Yazı İnkılâbı", BTTD, s. 40-41.

4 Özerdim, A.g.e., s. 16.

45 Cumhuriyet (Belgeler Eki), 1 Kasım 1978.
} 
İllerde valiler tahta başında, memurlara ders veriyordu. Devlet dairelerinde açılan kurslar arasında Diyanet İşleri Başkanlığı'nın kursu da vardı. Telgraf Genel Müdürlüğü ise, yeni harflerin rumuzunu saptamıştı.

Mustafa Kemal Paşa, 23 Ağustos - 20 Eylül tarihleri arasında, çeşitli illere geziler düzenlemiş, "Başöğretmen" olarak bu illerde halka okumayazma dersleri vermiştir. Bu geziler sırasında, yeni alfabede gereksiz gördüğü işaretleri kaldırmış, bunları bir tezkere ile Başbakanlığa bildirmiştir.

26 Ağustos'ta İstanbul'da bulunan milletvekillerine Mustafa Kemal Paşa'nın da bulunduğu toplantıda, yeni Türk harfleri konusunda İbrahim Necmi tarafından açıklamalar yapılmış, Devlet Basımevi'nde 50 bin tane basılan alfabeden dağıtılmıştır. Milli Eğitim Bakanı'nın, Türkiye Muallimler Birliği Kongresi'nde yaptığı konuşmanın konusu Yeni Türk Harfleri idi. Ağustos ayı sona ermeden İstanbul Belediyesi memurları yeni Türk harflerini kendiliklerinden öğrenmişler, açılması kararlaştırılan kursa gerek kalmamıştı. İstanbul Ticaret Odası, 17 Ağustos'ta çıkan ilânında; ticaret imzalarının yeni harflerle kaydına başlandığını, tüccar ve sanayicilerin yazışmalarını yeni harflerle yapmalarını bildiriyordu.

28 Ağustos'ta, Dolmabahçe Sarayı'nda profesörler, milletvekilleri, gazeteciler, yazarlar toplanarak yeni harfler üzerinde konuşmuşlardı. Bu konuşmada, İsmet Paşa, "Kabul edilen harfler Fransız harfleri değildir. Türk harfleri, Türk alfabesidir. Yeni alfabe bilimseldir ve Türk milletinin alfabesidir. Türklerin ihtiyaçlarına yeter" demiş ve İbrahim Necmi'ye şu kararı yazdırmıştı: "Milleti bilgisizlikten kurtarmak için, kendi diline uymayan Arap harflerini bırakıp, Latin esasından Türk harflerini kabul etmekten başka çare yoktur." Daha sonra bu karar oybirliği ile kabul edilmişti. ${ }^{46}$

Ağustos ayı böylece, yeni Türk harfleri için pek çok yol alınmı̧ olarak sona ermişti.

Eylül ayında ülkenin her tarafında kurslar devam etmiş, İstanbul'da çıkan gazeteler başlıklarını, işyerleri levhalarını değiştirmişler, milletvekilleri seçim bölgelerine dağılarak yeni harflerle ilgili konferanslar vermeye girişmişlerdi. 9 Eylül'de Halk Dersanelerinde derslere başlanmıştı. İsmet Paşa, "Bir öğretmen olarak gidiyorum" diyerek gittiği Malatya'da, halka hitaben yaptı̆̆ı uzun konuşmada, yeni harflerin kolay bir okumayazma aracı olduğuna değinerek sözlerini şöyle sürdürmüştür: “....... Bu kadar hayırlı ve kudretli bir tedbirin, niçin bugüne kadar geri bırakıldığını, istikbal münekkitlerine anlatmak kolay olmayacaktır. Fakat ben onlara diyeceğim ki; insanlar geleneğe o kadar bağlıdır ki, görenekten ayrılıp ve kat'i bir karara varabilmek için, Türk Devleti'nin Büyük Gazi gibi, türlü tecrübeler ve badireler içinde milletinin hayatiyet ve kudretinin özü gibi

th Özerdim, A.g.e., s. 20. 
yetişmek ve devlet reisi olduğu halde, köy köy dolaşıp alfabe hocalığı edecek kadar çalışkan, azimli ve fedakâr bir reisi gelmek lâzımdı., ${ }^{, 47}$

Milli Eğitim Bakanlığı, önce Türkçe derslerinin yeni harflerle okutulacağını bildirdiği halde, şimdi bir adım daha atmış ve 1 . ve 2 . sinıflarda bütün derslerin yeni harflerle yapılacağını, öteki sinıflarda ise, haftada 12 saatlik dersin Türkçe'ye ayrılacağını bildirmişti. Devlet Demiryolları ve Limanlar İdaresi'nin yeni harflerle bastırdığı tarife kitabı, Mustafa Kemal Paşa ile İsmet Paşa'yı sevindirmiş, ikisi de kitabın üzerine yeni harflerle imzalarını atmışlardı.

Öğretmenlere kurstan geçirildikten sonra sınav yapılacağı, başarılı olanlara belge verileceği, başarı gösteremeyenlerin 15 gün sonra yeniden sınava alınacağı, o zaman da başarı gösteremezlerse, öğretmenlikten çıkarılacakları bildirilmişti. Muhtar ve ihtiyar heyetleri üyeleri de, yeni harfleri öğrenemedikleri takdirde işlerinden çıkarılacaklardı.

1 Ekim'den başlayarak işyerlerinde yeni harflerle yazışma yapılacağı ve liseler dahil, bütün okulların ders kitaplarının yeni harflerle basılacağ bildiriliyordu. 11 Ekim'de gazeteler, yeni harflerle basılan ilk ders kitabının, Ali Canip (Yöntem)'in "Edebiyat" kitabı olduğunu yazıyorlardı.

29 Ekim'de, Milli Eğitim Bakanı bir demeç vererek, Bakanlığın, dilimizden Arap ve Acem kültürünü kaldıracak bütün önlemleri aldığını, Cumhurbaşkanı'nın “irşadı” ile bir söz derleme kurulu kurulacağını, dilimizin halk sözleri ile zenginleştirileceğini bildirmişti. Gazetelerde sıkışıp kalan bu haber, yeni Türk alfabesinin sağlayacağı büyük sonuçlardan birini müjdeliyordu. ${ }^{48}$

9 Ağustos 1928 gecesi, Sarayburnu Parkı'nda Mustafa Kemal Paşa'nın ünlü nutkuyla başlayan, yeni Türk harflerine halkı hazırlama dönemi; gezilerle, kurslarla, gazetelerle, başlık, levha, imza, bazı yazışmalar gibi küçük uygulamalarla, alfabe çalışmaları ve okullarda başlayan derslerle başlatılmış, bir yıla, üç yıla, beş yıla kadar diye yürütülen tahminleri geride bırakan bir hızla tam bir "devrim" adımı atılmıştı.

1 Kasım 1928 günü, Cumhurbaşkanı, Meclis'te açılış konuşmasını yaparken harf inkılâbı ile ilgili olarak şunları söylemiştir:

"Aziz Arkadaşlarım,

Herşeyden evvel her inkişafın yapı taşı olan meseleye temas etmek isterim. Her vasitadan evvel, büyük Türk milletine onun bütün emeklerini kısır yapan çorak yol haricinde kolay bir okuma-yazma anahtarı vermek lâzımdır. Türk milleti cehaletten az emekle, kısır yoldan ancak kendi güzel

47 Albayrak, M., A.g.m., s. 485.

48 Özerdim, A.g.e., s. 27. 
ve asil diline kolay uyan bir vasita ile siyrılabilir. Bu okuma-yazma anahtarı ancak Latin esasından alınan Türk alfabesidir. Basit bir tecrübe, Latin esasından Türk harflerinin Türk diline ne kadar uygun olduğunu, şehirde, köyde, yaşı ilerlemiş Türk evlatlarının ne kadar kolay okuyup yazdıklarını güneş gibi meydana çıkarmıștır. Büyük Millet Meclisi'nin kararıyla Türk harflerinin kat'iyet ve kanuniyet kazanması, bu memleketin yükselme mücadelesinde başlı başına bir geçit olacaktır. Milletler ailesine, münevver yetiştirmiş, büyük bir milletin dili olarak elbette girecek olan Türkçe'ye, bu yeni canlılı̆̆ kazandıracak olan Üçüncü Büyük Millet Meclisi, yalnız ebedi Türk tarihinde değil, bütün insanlık tarihinde de mümtaz bir sima kalacaktır.

Efendiler, Türk harflerinin kabulüyle hepimiz bu memleketin bütün vatanını seven yetişkin evlatlarına mühim bir vazife teveccüh ediyor. $\mathrm{Bu}$ vazife, milletimizin kâmilen okuyup-yazmak için gösterdiği şevk ve aşka bilfiil hizmet ve yardım etmektir. Hepimiz hususi ve umumi hayatımızda rastgeldiğimiz okuyup-yazma bilmeyen erkek-kadın her vatandaşımıza yeni harfleri öğretmek için tehalük göstermeliyiz...

Aziz arkadaşlarım, yüksek ve ebedi yadigârımızla, büyük Türk milleti yeni bir nur alemine girecektir., ${ }^{49}$

Mustafa Kemal Paşa'nın bu konuşmasından sonra, İsmet Paşa da, Meclis'te öncelikle görüşülmesini istediği, "Yeni Türk Harfleri Kanunu" tasarısı ile ilgili görüşlerini açıklamış ve yeni Türk harflerinin kolaylığından, halkı kısa zamanda cehaletten kurtaracağından söz etmiştir.

Diğer milletvekillerinin konuşmalarından sonra, TBMM, bir önerge ile verilmiş olan kanun tasarısını, tartışmasız oybirliği ile kabul etmiştir. Kanun'un kabul edilmesinden hemen sonra, Sivas Milletvekili Rahmi Bey'in, Mustafa Kemal Paşa'ya altın bir levha üzerinde kabartma harflerden bir “Türk Alfabesi”nin sunulması konusunda Meclis Başkanlığı'na vermiş olduğu önerge de, bu oturumda kabul edilmiştir. ${ }^{50}$

Latin esasına dayalı, fakat Türk dilinin fonetik özelliklerine göre düzenlenmiş ve seslendirilmiş bulunan yeni Türk Alfabesi'nin kabulü, üzerinde yıllardan beri yazılar yazılan, çekişmeler, tartışmalar yapılan alfabe sorununu kökünden çözmüştür.

3 Kasım 1928 günü, Cumhurbaşkanı tarafından onaylanan ve resmi gazetede yayınlanıp, yürürlüğe giren 1353 sayılı "Türk Harflerinin Kabulü ve Tatbiki Hakkında Kanun", 11 maddeden ibaretti. Bu kanuna göre; kanun yayınlandıktan sonra, bütün devlet dairelerinde, özel kurumlarda, Türk harfleriyle yazılan yazılar kabul edilecek, işlem görecekti. Uygulama tarihi, 1 Ocak 1929'u geçmeyecek, ancak tahkik evraklarının, fezlekelerin, basılı evrakın ve defterlerin yazılmas1, Haziran 1929'a kadar sürebilecekti. Eski

49 Atatürk'ün Söylev ve Demeçleri, Cilt I, s. 72-79.

50) Ülkütaşır, A.g.e., s. 87. 
yazı ile dilekçeler de bu tarihe kadar kabul edilecekti. Gazete, dergi, levha, ilân, reklâm gibi basmalar, 1 Aralık 1928'den başlayarak yeni harflerle çıkarılacaktı. 1929 Ocak ayından sonra ise, artık bütün kitaplar yeni harflerle basılacaktı. Tutanaklarda eski harfler, Haziran 1929'a kadar steno gibi kullanılabilecek, devlet dairelerinde faydalanılan kitap, yönetmelik, defter, cetvel gibi şeyler ise, Haziran 1930'a kadar kalabilecekti. Para, pul, bono gibi değerli kâğıtlar değiştirilinceye kadar geçerli olacaktı. Okullarda dersler yeni harflerle yapılacaktı. Kanun'da devlet daireleri için konulan hükümler, bankalar, şirketler, dernekler için de uygulanacaktı. Bu arada, bütün memurların sınavdan geçirileceği günler de saptanmıştı. Başarılı olanlara, yeni Türkçe yazıyla hazırlanan "Ehliyetnâme" verilecekti.

Ülkenin her yanında görülen okuma-yazma seferberliğine, devletin yoğun desteği sayesinde rağbet büyük olmuştu. Fakat başlangıçta bu faaliyetler örgütlenememiş, disiplinsiz bir durumda idi. Mustafa Kemal Paşa, bunun bir örgüt bünyesine alınmasını ve daha disiplinli çalıştırılmasını istedi. Böylelikle bu konu, hükümet programına girmiş oldu ve Millet Mektepleri'nin kurulması kararı da bu fikirlerin ve çabaların sonunda alındı.

30 Kasım 1928'de gazeteler son olarak eski harflerle yayınlandı. Ayrıca, yeni harflerin kolay ve çabuk öğrenilmesini sağlamak amacıyla, "Gazete Primleri Kanunu" kabul edilerek gazetelere prim verilmesi sağland. Böylece gazeteler daha kısa zamanda, yeni harflerle basım yapma olanağına kavuşturuldu. Bu prim, gazetelerin makine ve öteki basım araç-gereçlerini kısa zamanda yenilemelerini sağlamak amacıyla verilmişti. ${ }^{51}$

\section{HARF INKILÂBININ UYGULANMASI}

Türkiye'de, 1927 yılında okur-yazarlık oranı, kadınlarda \% 4, erkeklerde \% 13 ve genel nüfusa göre \% 8.16 idi. Bunun \% 5-6'sı eski yazıyı bilen Türklerde, geri kalanı gayrimüslimlerde ve öteki dillerde idi. Kentlerde okur-yazarlık oranı $\% 30$, köylerde $\% 6$ civarında idi ${ }^{52}$

Harf inkılâbı yapıldıktan hemen sonra Halk Eğitim Kurumları'nın "Millet Mektepleri" adı altında örgütlenmesi çabaları başlatıldı. İsmet Paşa, 8 Kasım 1928'de bu konuda açıklama yaparken:

“Türk harflerinin bütün vatandaşlara kapılarının önünde ve işlerinin başında öğretilebilmesi için daha bu yıl içinde Millet Mektepleri'nin teşkilâtını kuracağız." demiş ve düşündükleri esasları şöyle açıklamıştır: "Bu teşkilât şehir ve köy bütün yurdu kaplayacak, vatandaşların işlerinin, maişetlerinin en uygun zamanlarında ve yanlarında ya iki aylık veya dört aylık kurslar açılacak, şehirde ve köyde mektepler, belirli toplanma yerlerinde de, gelmeye zamanları olmayan vatandaşlar için seyyar öğretmen

${ }^{51}$ Ayın Tarihi, Cilt 22, 1930, s. 6031.

${ }^{52}$ Başgöz, İlhan - Howard, W., Türkiye Cumhuriyeti'nde Eğitim, Ankara - 1968, s. 117-145. 
teşkilâtı yapılacak, devletin en büyüğünden en küçügüune kadar bütün memurları, Millet Mektepleri teşkilâtının ihtiyacına göre çalışacaklardır. Cumhurbaşkanımız Hazretleri, Millet Mektepleri teşkilâtının genel başkanlığını ve başöğretmenliğini kabul buyurmuşlardır." 53

T.C. Hükümeti tarafından hazırlanan Millet Mektepleri ile ilgili kararname, Kasım 1928'de, Resmi Gazete'de yayınlanarak yürürlüğe konuldu. Bu Talimatname'ye göre; Millet Mektepleri, yeni Türk harflerinin kolay bir şekilde okunup yazılmasından bütün milleti yararlandırabilmek ve büyük halk kitlelerini hızla okur-yazar durumuna getirebilmek için kuruluyordu.

Milli Eğitim Bakanı Mustafa Necati Bey, 2 Aralık 1928 günü valiliklere bir genelge göndererek, Millet Mektepleri'nde 1 Ocak 1929'dan itibaren derslere başlanacağını, bunun için o zamana kadar, her öğretmene bir millet mektebi dersanesi kurulacağını, bir kurs döneminde başarılı olmayanların, öbür kursa katılacaklarını, tek öğretmenli köylerde hem A, hem de B dersanesi açılacağını ve diğer bilgileri verdikten sonra, 10 Ocak 1929'da bu işlerle ilgili sayısal bilgileri ve karşılaşılan zorlukları, Bakanlığa bildirmelerini istemişti. ${ }^{54}$

24 Kasım 1928'de yürürlüğe giren "Millet Mektepleri Talimatnamesi" 15 bin adet basılarak ülkenin her yanına gönderilmiş ve yönetmelik maddeleri; valiler, kaymakamlar, eğitim müdürleri tarafından okunup, hemen uygulamaya geçilmiştir. Yönetmeliğin 1. maddesinde yeralan; "Türkiye halkını okuyup yazmaya muktedir bir hale getirmek, ana bilgileri kazandırmak" ifadesi ile Millet Mektepleri'nin amacı belirtilmiştir.

Yine Yönetmeliğe göre; Millet Mektepleri örgütü, A ve B dersaneleri ile halk okuma odaları ve köy yatı dersanelerinden oluşmaktadır. Millet Mektepleri'nin Genel Başkanı, Cumhurbaşkanı Gazi Mustafa Kemal Paşa'dır. 16-45 arasındaki tüm vatandaşlar, bu okullara devam etmeye veya dışarıdan sınava girerek belge almaya zorunlu tutulmuşlardır. Öğretmeni veya okulu olmayan köylerde, gidip onlara yeni yazıyı öğretecek "Seyyar Talim Heyetleri" kurulmuştur.

Yeni Türk harfleriyle yapılacak öğretime uygun olarak hazırlanmış "Alfabe", bu okulların ilk ders kitabı olmuş, resimli olan bu kitapta, Cumhurbaşkanı'nın Millet Mektepleri öğrencilerine hitabesi de yer almıştır. Okutulan diğer önemli kitaplar ve dersler; Kıraat Kitabı ve Yurt Bilgisi Kitabı ile, Okuma, Yazma, Sağlık Bilgisi, Yurt Bilgisi, Hesap ve Ölçüler dersleridir.

53 Albayrak, Mustafa, Millet Mektepleri (1928-1935), A.Ü. D.T.C.F., Mezuniyet Tezi. Ankara - 1978.

\$4 Maarif Vekâleti Mecmuası, s. 17, s. 89-90. 
Devletin bu okullar konusundaki ciddi tutumu ve takipçiliği, ayrıca vatandaşların şevk ve heyecanla öğretimi sürdürmeleri verimli sonuçlar alınmasını sağlamıştır. Her ailede bireylerin okuma-yazma öğrenmelerinden aile reisi sorumlu tutulmuştur.

Millet Mektepleri, başlangıçta inkılâbın coşkusuyla, halka yalnızca okuma-yazma öğretmeyi amaçlayan bir örgüt olarak ortaya çıkmış, daha sonra zorunlu ve genel halk eğitimini amaçlamıştır. Eski harfleri bilenlere de yeni harfleri öğretmek ve halka temel bilgiler kazandırmak, bu mekteplerin başlıca amaçları olmuştur.

16-45 yaş arasındaki vatandaşların devam ettiği ve varlıklarını 1936 yılına kadar sürdüren bu kurumlarda 1928-1935 yılları arasında ülkede, yeni harflerle yaklaşı 2,5 milyon insana okuma-yazma öğretilmiştir. Aslında Harf İnkılâbı ile, daha önce okuma-yazma bilenler de, bilmeyen durumuna düştükleri için bu rakam 3,5 milyona yaklaşmaktadır. Yani nüfusun dörtte biri okur-yazar duruma getirilmiştir. ${ }^{55} \mathrm{O}$ dönemin koşullarındaki zorluk düşünüldüğünde bunun, önemli bir ilerleme olduğu anlaşılmaktadır.

\section{SONUÇ}

Türkler V. yüzyıldan itibaren çeşitli dönemlerde ve bölgelerde bağlı bulundukları inançlara ve girdikleri kültür çevrelerine göre Kök-Türk ve Uygur alfabelerinin yanısıra çeşitli alfabeler kullanmışlardır.

Türklerin İslâm dinini kabul etmeleriyle birlikte, XI. yüzyılın başlarından itibaren Arap alfabesi, Türkler arasında yayılmış ve Türkçe'ye uygulanmıştır. Arap alfabesinin Türkçe'ye uygulanması, birçok aşamalar geçirmiş, sürekli yazım kuralları değişmiş ama Arap harfleri hiçbir dönemde Türkçe için kullanışlı bir yazı olmamıştır. Arap alfabesindeki harflerin, Türkçe ses yapısına uymaması, basın-yayın hayatında zorluklara neden olması, kolay okunup yazılamaması, bu alfabenin iyileştirilmesi veya değiştirilmesi fikrini gündeme getirmiştir.

İlk girişim, 1860'lı yılların başında Münif Paşa tarafından başlatılmış ve 1928 yılına kadar bu konudaki öneriler, tartışmalar ve çalışmalar sürüp gitmiştir. Ancak bu süre içinde, bir sonuca ulaşılamamıştır. Bu öneriler ve tartışmalar Cumhuriyet'in ilk yıllarında daha da önem kazanmış, gerek basında, gerekse TBMM'de güncelliğini korumuştur.

Uzun yıllar süren tartışmaların sonunda Atatürk, alfabe sorununu, inkılâpları arasına alarak sistemli bir şekilde çalışmalara başlamıştır. Dil Encümeni ve Alfabe Komisyonu'nu kurarak çeşitli alfabeleri inceletmiş, sonunda Latin kökenli harflerin Türkçe dil yapısına uygun şekle getirilmesine karar verilmiştir.

55 Kodamanoğlu, N., Türkiye'de Eğitim (1923-1960), Ankara - 1964, s. 30-31. 
9 Ağustos 1928 'de Sarayburnu Parkı'nda yapılan bir toplantıda, yeni Türk alfabesini davetlilere tanıtarak Türk Harf İnkılâbı'nı başlatmıştır. 1 Kasım 1928 günü Meclis yeni Türk Harfleri Kanunu'nu kabul etmiş, 3 Kasım 1928 günü, bu Kanun, Resmi Gazete'de yayınlanarak yürürlüğe girmiştir.

9 Ağustos 1928 'den itibaren, basının da desteği ile ülkede yeni Alfabe'nin benimsenmesi, öğrenilmesi ve yaygınlaştırılması amacıyla ciddi çabalar başlatılmıştır.

Yeni Türk harfleri okuma-yazmayı büyük ölçüde kolaylaştırdığı için, ülke çapında -devletin ve basının da desteği ile- okuma-yazma yaygınlaştırılmış ve halk eğitimi gerçekleştirilmiştir.

Atatürk, Türk milletinin, uygar milletler arasına girmesini kolaylaştırmak ve bunu sağlamak için yeni Türk alfabesinin kabulünü zorunlu görmüştür. Çağdaş uygarlığa giden yolu Türk milletine açmak, onun çağdaş uygarlık seviyesinin üstüne çıkmasını sağlamak amacının yanısıra, alfabe değişikliğinin diğer büyük amacı da millileşmek, milli kültürümüzü oluşturmaktır.

Türk Harf İnkılâbı ile, Türk kültür hayatını yepyeni ufuklara, evrenselliğe götürecek adımların ilki ve en büyüğü atılmıştır.

\section{KAYNAKLAR}

Albayrak, Mustafa, Millet Mektepleri 1928-1935, A.Ü.D.T.C.F., Mezuniyet Tezi, Ankara, 1978 .

Albayrak, Mustafa, "Yeni Türk Harflerinin Kabulü Öncesinde Halk Eğitimi ve Yazı Değişimi Konusunda Türk Kamuoyunda Bazı Tartışmalar ve Millet Mekteplerinin Açılması", Atatürk Yolu, Kasım 1989, Yıl 2.

Ankara Doğu Araştırma Merkezi, “Türk Yazı İnkılâbının Fikri Hazırlıkları”, BTTD, İstanbul - 1985.

Atatürk, Mustafa Kemal, Atatürk'ün Söylev ve Demeçleri, C. I-IV, Ankara 1961.

Atatürk, Mustafa Kemal, "Türk Yazı İnkılâbı”, BTTD, İstanbul - 1985.

Atay, Falih Rıfkı, Çankaya, İstanbul - 1984.

Ayın Tarihi, Cilt 22, 1930.

Başgöz, İlhan - Howard, E. Wilson, Türkiye Cumhuriyeti'nde Eğitim, Ankara 1968.

Canbolat, Mustafa, “Türkiye'de Yazı Devrimi Girişimleri”, Yazı Devrimi, Ankara 1979. 
Cumhuriyet (Belgeler Eki), 1 Kasım 1978.

Dilaçar, A., “Türk Yazısının Geçirdiği Evreler”, BTTD, İstanbul 1985.

Erdentuğ, Nermin, “Atatürk’te Kültür Dinamizmi Görüşü̈, Cumhuriyet'in 50. Yıldönümü Anma Kitabı, Ankara - 1974.

Eren, Hasan, "Yazıda Birlik", Harf Devriminin 50. Yılı Sempozyumu, Ankara 1981.

Ergün, Mustafa, Atatürk Devri Türk Eğitimi, Ankara - 1982.

Hakimiyet-i Milliye, 5 Mart 1923.

Hür Fikir, 17 Kasım 1926.

Hürriyet-i Fikriye, Mart-Nisan 1914.

İçtihad, Haziran, Temmuz, Ağustos 1923.

İnönü, İsmet, Hatıralar, C. II, Ankara - 1987.

Karal, Enver Ziya, "Osmanlı Tarihinde Türk Dili Sorunu”, Bilim-Kültür ve Öğretim Dili Olarak Türkçe, Ankara - 1978.

Levend, Agah Sırrı, "Latin Harfleri Meselesi”, BTTD, İstanbul-1985

Lewis, Bernard, Modern Türkiye'nin Doğuşu, Çev. Metin Kıratlı, Ankara - 1984.

Maarif Vekâleti Mecmuası, Sayı: 17.

Mecmua-i Fünûn, 1868.

Özerdim, S. Nabi, Harf Devriminin Öyküsï, Ankara - 1962.

S. Nabi, Harf Devriminin Öyküsü, Ankara - 1962.

Şimşir, Bilal N., “Amerikan Belgelerinde Türk Yazı Devrimi”, Belleten, C. XLIII, Sayı: 169.

Tanin, 20-31 Ocak 1910.

Tansel, Fevziye Abdullah, “Arap Harflerinin Islahı ve Değiştirilmesi Hakkında İlk Teşebbüsler (1862-1884)”, Belleten, C. XVII.

Tezcan, Semih, “Türkler’de Yazı Kültürünün Başlangıcı ve Gelişimi”, Harf Devriminin 50. Yılı Sempozyumu, Ankara - 1981.

Türk Yurdu, No: 6, 1926.

Ülkütaşır, M. Şakir, Atatürk ve Harf Devrimi, Ankara - 1981.

Yalçın, Hüseyin Cahit, "Latin Harfleri”, Resimli Gazete, 22 Eylül 1923. 